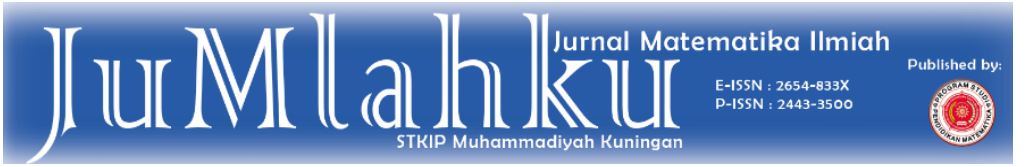

Submited: 2020-10-22

Published: 2020-12-04

\title{
Pengembangan Instrumen Tes Kemampuan Berpikir Kreatif Matematis Untuk Siswa SMK Pada Materi Statistika
}

Yosi Adiputraa), Handayani Eka Putrib)

a,b) Akademi Maritim Cirebon

yosiadiputra@gmail.coma), handayaniekaputri1990@gmail.com ${ }^{\text {b) }}$

\begin{tabular}{|c|c|}
\hline Article Info & Abstract \\
\hline $\begin{array}{l}\text { Kaywords : Development, } \\
\text { Mathematical Creative } \\
\text { Thinking, Validation }\end{array}$ & $\begin{array}{l}\text { Developing creativity needs to be done because this ability is one of } \\
\text { the abilities which needed at this time. The ability to think creatively } \\
\text { also can improve the quality of human resources that it can lead the } \\
\text { country into a prominent position or at least equal to the other } \\
\text { countries. Therefore, learning needs to be designed in such a way as } \\
\text { to bring out the potential for student creativity, including learning } \\
\text { mathematics. To find out this potential, an appropriate measuring } \\
\text { instrument is needed. The development of the ability to think } \\
\text { creatively needs to be done in line with developing ways of measuring } \\
\text { it. The mathematical creative thinking ability test (TKBKM) has been } \\
\text { compiled and validated in terms of face and content, and has a high } \\
\text { coefficient of validity and reliability. The test also has good } \\
\text { distinguishing power (DP) and has a moderate level of difficulty (TK). } \\
\text { Thus the items in the Mathematical Creative Thinking Ability (KBKM) } \\
\text { test can be used in data collection research. }\end{array}$ \\
\hline
\end{tabular}


Kata Kunci:

Pengembangan, Berpikir Kreatif Matematis, Validasi

\begin{abstract}
Abstrak
Menumbuhkembangkan kreatifitas perlu dilakukan karena kemampuan ini merupakan salah satu kemampuan yang dibutuhkan pada zaman ini. Kemampuan berpikir kreatif juga dapat meningkatkan kualitas sumber daya manusia sehingga dapat menghantarkan negara ke dalam posisi terkemuka atau paling tidak sejajar dengan negaranegara lain. Oleh karena itu, Pembelajaran perlu dirancang sedemikian rupa untuk memunculkan potensi kreatifitas siswa, termasuk pembelajaran matematika. Untuk mengetahui potensi tersebut diperlukan suatu alat ukur yang tepat. Pengembangan kemampuan berpikir kreatif perlu dilakukan sejalan dengan pengembangan cara mengukurnya. Tes kemampuan berpikir kreatif matematis (TKBKM) telah disusun dan divalidasi dari segi muka dan isi, serta memiliki koefisien validitas dan reliabilitas yang tinggi. Tes tesebut juga memiliki daya pembeda (DP) yang baik dan memiliki tingkat kesukaran (TK) yang sedang. Dengan demikian butir soal tes Kemampuan berpikir kreatif matematis (KBKM) ini dapat gigunakan dalam pengumpulan data penelitian.
\end{abstract}

\section{PENDAHULUAN}

Tantangan masa depan yang selalu berubah sekaligus persaingan yang semakin ketat memerlukan lulusan pendidikan yang tidak hanya terampil dalam satu bidang, tetapi juga kritis dan kreatif dalam mengembangkan bidang yang ditekuni. Hal ini perlu diterapkan dalam setiap mata pelajaran di sekolah, terutama matematika. Oleh karena itu, mata pelajaran matematika yang berorientasi pada masalah perlu diberikan kepada semua perserta didik mulai dari sekolah dasar untuk membekali peserta didik dengan kemampuan berpikir logis, analitis, sistematis, kritis, dan kreatif, serta kemampuan bekerjasama. (Permendikbud, 2006)

Kreatifitas merupakan salah satu kemampuan yang dibutuhkan pada zaman ini. Dengan kreatifitas, seseorang dapat memberikan manfaat untuk orang lain, juga dapat memudahkan orang lain dalam menjalankan aktivitasnya.

Permendikbud No 34 Tahun 2018 tentang standar kompetensi lulusan Sekolah Menengah Kejuruan (SMK) menyatakan bahwa lulusan SMK harus memiliki kemampuan untuk mencari dan menghasilkan gagasan, cara kerja, layanan dan produk karya inovatif sesuai keahliannya serta memiliki kemampuan bekerjasama menyelesaikan masalah dalam melaksanakan tugas sesuai keahliannya secara kreatif.

Ditinjau dari aspek kehidupan manapun, kebutuhan akan kreativitas sangatlah penting. Kreativitas dapat meningkatan kualitas sumber daya manusia. Sumber daya manusia yang berkualitas akan menghantarkan Indonesia ke posisi terkemuka, atau paling tidak sejajar dengan negara-negara lain, baik 
dalam pembangunan ekonomi, politik, maupun sosial budaya. (Nunuk, 2019).

Pembelajaran matematika merupakan salah satu pembelajaran dimana dalam prosesnya menunut siswa untuk berpikir kreatif. Di dalam proses pembelajaran pada materi statistika, siswa dituntut kreatif untuk menemukan informasi dari data yang diberikan dengan cara mengamati, mengolah informasi yang didapatkan, menyimpulkan dan mempresentasikan hasil pengamatannya menjadi suatu interpretasi data yang dibagikan kepada teman-temannya.

Dari uraian di atas, kreatifitas lulusan SMK perlu ditumbuhkembangkan demi menghadapi persaingan global serta arus informasi yang berjalan sangat cepat. Pembelajaran perlu dirancang sedemikian rupa untuk memunculkan potensi kreatifitas siswa, termasuk pembelajaran matematika. Untuk mengetahui potensi tersebut diperlukan suatu alat ukur yang tepat. Maka dari itu, peneliti melakukan penelitian untuk mengembangkan suatu alat ukur atau instrumen yang dapat mengukur kreatifitas siswa dalam pembelajaran matematika.

Peneliti telah membuat instrumen Tes Kemampuan Berpikir Kreatif Matematis (TKBKM) untuk siswa SMK. Penelitian pengembangan instrumen ini dilakukan melalui serangkaian uji coba dan analisis terhadap hasil uji coba yang dilakukan terhadap instrumen tersebut.

\section{METODE PENELITIAN}

\begin{abstract}
Penelitian ini merupakan penelitian dan pengembangan (Research and Development) yang bertujuan untuk
\end{abstract} 58 mengembangkan instrumen tes untuk mengukur kemampuan berpikir kreatif matematis siswa yang valid dan reliabel dalam pembelajaran matematika. Sugiyono (2011) berpendapat bahwa, metode penelitian dan pengembangan (R\&D) adalah metode penelitian yang digunakan untuk menghasilkan produk tertentu, dan menguji keektifan produk tersebut. Untuk dapat menghasilkan produk tertentu digunakan penelitian yang bersifat analisis kebutuhan (digunakan metode survey atau kualitatif) dan untuk menguji keefektifan produk tersebut supaya dapat berfungsi di masyarakat luas, maka diperlukan penelitian untuk menguji keektifan produk tersebut (digunakan metode eksperimen).

Model pengembangan yang digunakan dalam penelitian ini adalah model penngembangan plomp (Arsyad, 2016). Model pengembangan plomp terdiri dari lima tahap, yaitu: (1) tahap pengkajian awal (Preliminary Investigation Phase), (2) tahap perancangan (Design Phase), (3) tahap realisasi/ konstruksi (Realization/ Construction Phase), (4) tahap tes, evaluasi dan revisi (Test, Evaluation and Revision Phase), dan (5) tahap implementasi (Implementation Phase).

Langkah - langkah dalam pengembangan instrumen tes untuk mengukur kemampuan berpikir kreatif matematis adalah sebagai berikut : 


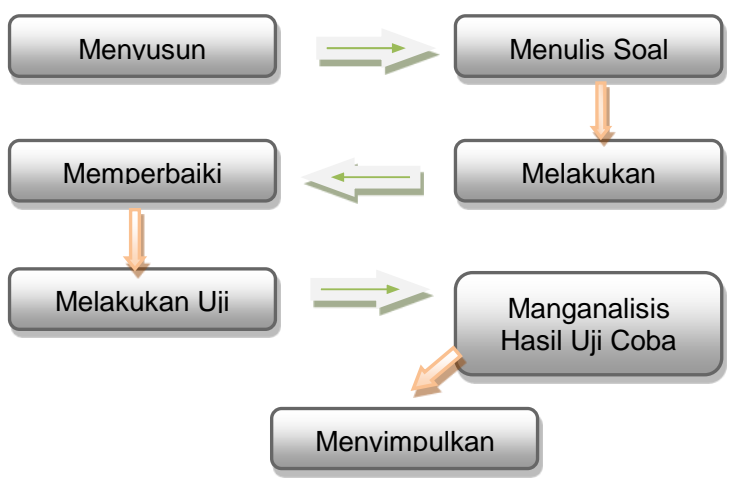

Gambar 1 :Langkah-langkah Pengembangan Instrumen Tes

Dalam penelitian ini, teknik pengumpulan data yang dilakukan adalah dengan menggunakan instrumen tes kemampuan berpikir kreatif matematis serta angket penilaian validasi muka dan validasi isi yang dilakukan oleh ahli di bidang pendidikan matematika sebanyak 5 orang yang terdiri dari 1 orang mahasiswa program S3 Pendidikan Matematika, 3 orang dosen pendidikan matematika serta 1 orang guru matematika. Data yang diperoleh berupa data kualitatif dan kuantitatif. Data kualitatif diperoleh dari isntrumen validasi ahli yang berisi komentar dan saran untuk perbaikan instrumen. Sedangkan data kuantitatif diperoleh dari skor pada uji coba tes yang dilakukan kepada 30 siswa kelas XII secara acak.

Pada lembar validasi muka dan isi, penimbang menceklis setiap jenis pernyataan dengan pada kolom "Ya" atau "Tidak". Jika penimbang memilih "Ya" maka skornya 1 dan jika memilih "Tidak" maka skornya 0 . Berikut adalah angket validasi muka dan validasi isi.

\begin{tabular}{|c|c|c|c|c|c|c|c|c|c|}
\hline \multirow{2}{*}{\multicolumn{2}{|c|}{ Jenis Perşyaratan }} & \multicolumn{8}{|c|}{ Nomor Soal } \\
\hline & & \multicolumn{2}{|c|}{1} & \multicolumn{2}{|c|}{2} & \multicolumn{2}{|c|}{3} & \multicolumn{2}{|c|}{4} \\
\hline \multicolumn{2}{|r|}{ Validitas Muka } & $\mathrm{Ya}$ & Tdk & $\mathrm{Ya}$ & Tdk & $\mathrm{Y}_{\mathrm{a}}$ & Tdk & $\mathrm{Ya}_{\mathrm{a}}$ & Tdk \\
\hline 1 & Instrumen dapat terbaca dengan jelas & & & & & & & & \\
\hline \multicolumn{2}{|r|}{2 Instrumen dikembangkan sesuai dengan indikator yang ingin dicapai } & & & & & & & & \\
\hline \multicolumn{2}{|r|}{3 Bahasa yang digunakan komunikatif } & & & & & & & & \\
\hline 4 & Kalimat dalam instrumen dapat dipahami dengan baik & & & & & & & & \\
\hline 5 & Rumusan kalimat tidak menimbulkan penafsiran ganda atau salah pengertian & & & & & & & & \\
\hline 6 & Bahasa yang digunakan tidak menyinggung SARA dan orang lain & & & & & & & & \\
\hline 7 & Penyusunan instrumen sudah mengikut kaidah penulisan & & & & & & & & \\
\hline \multicolumn{2}{|r|}{8 Butir soal memuat informasi yang cukup } & & & & & & & & \\
\hline \multicolumn{10}{|c|}{ Valid } \\
\hline \multicolumn{10}{|c|}{ Tidak Valid } \\
\hline \multicolumn{2}{|r|}{ Valid (Perlu Perbaikan) } & & & & & & & & \\
\hline
\end{tabular}

\begin{tabular}{|c|c|c|c|c|c|c|c|c|c|}
\hline \multirow{3}{*}{\multicolumn{2}{|c|}{$\begin{array}{l}\text { Jenis Persyaratan } \\
\text { Validitas Isi/Materi }\end{array}$}} & \multicolumn{8}{|c|}{ Nomor / Butir Soal } \\
\hline & & \multicolumn{2}{|c|}{1} & \multicolumn{2}{|c|}{2} & \multicolumn{2}{|c|}{3} & \multicolumn{2}{|c|}{4} \\
\hline & & \multicolumn{2}{|c|}{\begin{tabular}{l|l}
$Y_{a}$ & $T d k$
\end{tabular}} & \multirow[t]{2}{*}{$\mathrm{Ya}_{\mathrm{a}}$} & \multirow[t]{2}{*}{ Tdk } & \multirow[t]{2}{*}{ Ya } & \multirow[t]{2}{*}{$\mathrm{Tdk}$} & \multirow[t]{2}{*}{$\mathrm{Ya}$} & \multirow[t]{2}{*}{ Tdk } \\
\hline 1 & Butir soal sesuai dengan materi pembelajaran & & & & & & & & \\
\hline 2 & Materi butir soal sesuai dengan tujuan pembelajaran & & & & & & & & \\
\hline 3 & Materi yang ditanyakan sesuai dengan jenjang, jenis sekolah dan tingkat kelas & & & & & & & & \\
\hline 4 & Butir soal memuat informasi yang cukup & & & & & & & & \\
\hline 5 & Kesesuaian urutan materi & & & & & & & & \\
\hline 6 & Butir soal dikembangkan sesuai dengan indikator yang ingin dicapai & & & & & & & & \\
\hline \multirow[t]{4}{*}{7} & Butir soal sesuai dengan tujuan penilaian yang ingin dicapai & & & & & & & & \\
\hline & Valid & & & & & & & & \\
\hline & Tidak Valid & & & & & & & & \\
\hline & Valid (Perlu Perbaikan) & & & & & & & & \\
\hline
\end{tabular}

Sedangkan untuk tes kemampuan berpikir kreatif matematis disusun dengan bentuk uraian berdasarkan kriteria berpikir kreatif dan materi ajar yang dipelajari siswa. Sebelum tes tersebut digunakan, terlebih dahulu dilakukan uji validitas dan realibilitas tes. Untuk kisi-kisi dan soal tes kemampuan berpikir kreatif matematis, ditunjukkan pada lampiran 1 dan 2.

Untuk memperoleh data kemampuan berpikir kreatif matematis, dilakukan penskoran terhadap jawaban siswa untuk setiap butir soal. Adapun 
kriteria penskoran tes kemampuan berpikir kreatif matematis yang digunakan pada penelitian ini adalah mengacu pada skor rubrik yang dikembangkan oleh Bosch (Ismaimuza, 2010) yang ditunjukkan pada lampiran 3

Setelah penskoran dilakukan, maka akan dihitung koefisien validitas dari setiap butir soal serta reliabilitas dari keseluruhan instrumen tes. Untuk menentukan validitas masing-masing soal digunakan korelasi product moment pearson dari Carl Pearson (Arikunto, 2003), sedangkan untuk mencari reliabilitas soal bentuk uraian digunakan rumus Alpha Cronbach (Suherman, 2003).
Selain itu, akan dihitung pula Daya Pembeda dan Indeks Kesukaran soal.

\section{HASIL DAN PEMBAHASAN}

Pada tahap uji validitas muka dan validitas isi oleh para penimbang, peneliti mengelompokkan hasil penilaian para penimbang untuk setiap nomor soal. Selanjutnya dilakukan uji statistik $Q$ Cochran yang bertujuan untuk mengetahui pendapat para penimbang seragam atau tidak dalam melakukan pertimbangan. Adapun penilaian dari seluruh penimbang disajikan dalam tabel berikut :

\section{Tabel 1. Hasil Validasi Muka Tes Kemampuan Berpkir Kreatif Matematis}

\begin{tabular}{|c|c|c|c|c|c|c|c|c|c|c|c|c|}
\hline \multicolumn{6}{|c|}{$\begin{array}{l}\text { Validitas Muka } \\
\text { Soal No. } 1\end{array}$} & & \multicolumn{6}{|c|}{$\begin{array}{l}\text { Validitas Muka } \\
\text { Soal No. } 2\end{array}$} \\
\hline \begin{tabular}{l|l} 
Pernyataan \\
\end{tabular} & v1 & V2 & V3 & V4 & V5 & & Pernyataan & V1 & V2 & V3 & V4 & V5 \\
\hline 1 & 1 & 1 & 1 & 1 & 1 & & 1 & 1 & 1 & 1 & 1 & 1 \\
\hline 2 & 1 & 1 & 1 & 1 & 1 & & 2 & 1 & 1 & 1 & 1 & 1 \\
\hline 3 & 1 & 1 & 1 & 1 & 0 & & 3 & 1 & 1 & 1 & 1 & 0 \\
\hline 4 & 1 & 1 & 1 & 1 & 1 & & 4 & 1 & 1 & 1 & 1 & 0 \\
\hline 5 & 1 & 1 & 1 & 1 & 1 & & 5 & 1 & 1 & 1 & 1 & 1 \\
\hline 6 & 1 & 1 & 1 & 1 & 1 & & 6 & 1 & 1 & 1 & 1 & 1 \\
\hline 7 & 1 & 1 & 1 & 0 & 1 & & 7 & 1 & 0 & 1 & 1 & 1 \\
\hline 8 & 1 & 1 & 1 & 1 & 1 & & 8 & 1 & 1 & 1 & 1 & 1 \\
\hline \multicolumn{7}{|c|}{$\begin{array}{l}\text { Validitas Muka } \\
\text { Soal No. } 3\end{array}$} & \multicolumn{6}{|c|}{$\begin{array}{l}\text { Validitas Muka } \\
\text { Soal No. } 4\end{array}$} \\
\hline Pernyataan & V1 & $\mathrm{V}_{2}$ & 2 & 13 & V4 & V5 & Pernyataan & V1 & V2 & V3 & V4 & V5 \\
\hline 1 & 1 & 1 & 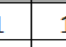 & 1 & 1 & 1 & 1 & 1 & 1 & 1 & 1 & 1 \\
\hline 2 & 1 & 1 & L & 1 & 1 & 1 & 2 & 1 & 1 & 1 & 1 & 1 \\
\hline 3 & 0 & 1 & & 1 & 1 & 1 & 3 & 1 & 0 & 1 & 1 & 0 \\
\hline 4 & 1 & 1 & & 1 & 1 & 0 & 4 & 1 & 1 & 1 & 1 & 0 \\
\hline 5 & 1 & 1 & & 1 & 1 & 1 & 5 & 1 & 1 & 1 & 1 & 1 \\
\hline 6 & 1 & 1 & & 1 & 1 & 1 & 6 & 1 & 1 & 1 & 1 & 1 \\
\hline 7 & 1 & 1 & & 1 & 1 & 1 & 7 & 0 & 1 & 1 & 1 & 0 \\
\hline 8 & 1 & 1 & & 1 & 1 & 1 & 8 & 1 & 1 & 1 & 1 & 1 \\
\hline
\end{tabular}


Dari hasil penilaian seluruh penimbang, tampak bahwa pada setiap butir soal, lebih banyak angka 1 daripada angka 0 . Artinya setiap penimbang menilai bahwa validitas muka instrumen tes kemampuan berpikir kreatif matematis sudah terpenuhi. Akan tetapi, untuk lebih meyakinkan apakah penilaian masingmasing penimbang sama atau tidak, akan dilakukan uji statistik Q-Cochran dengan menggunakan SPSS. Berikut adalah outputnya :

Tabel 2. Uji Q-Cochran Validitas Muka TKBKM

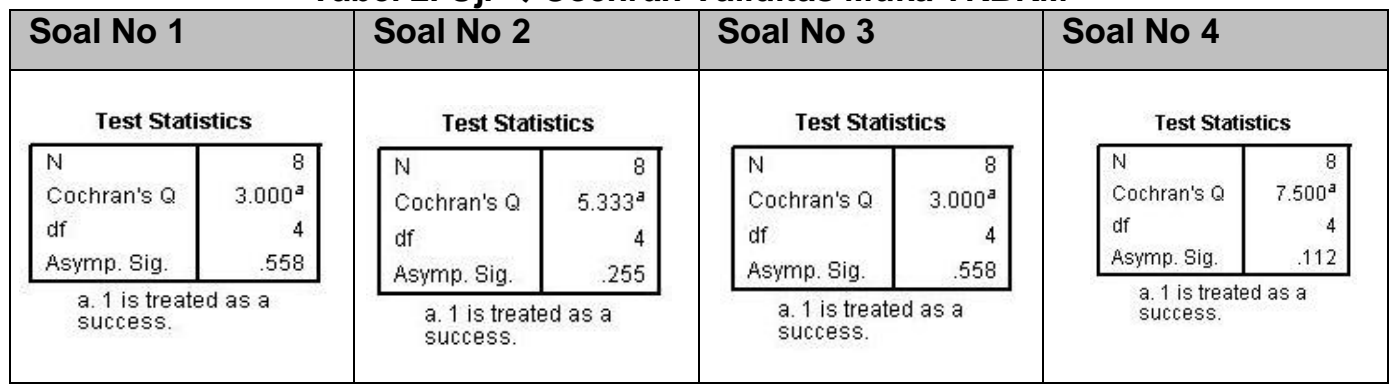

Dari Tabel 2 di atas terlihat bahwa taraf signifikansi untuk butir soal nomor 1 adalah 0,558 , butir soal nomor 2 sebesar 0,255 , nomor 3 sebesar 0,558 dan nomor 4 sebesar 0,112 . Taraf signifikansi keempat butir soal tersebut lebih besar dari taraf signifikansi $\alpha=0,05$. Maka dapat disimpulkan bahwa para penimbang telah melakukan validasi muka setiap butir soal tes kemampuan berpikir kreatif matematis secara sama atau seragam. Selanjutnya peneliti juga melakukan validasi isi yang hasilnya dapat dilihat pada Tabel 3 berikut.

Tabel 3. Hasil Validasi Isi Tes Kemampuan Berpkir Kreatif Matematis

\begin{tabular}{|c|c|c|c|c|c|c|c|c|c|c|c|}
\hline \multicolumn{6}{|c|}{$\begin{array}{l}\text { Validitas Isi } \\
\text { Soal No. } 1\end{array}$} & \multicolumn{6}{|c|}{$\begin{array}{l}\text { Validitas Isi } \\
\text { Soal No. } 2\end{array}$} \\
\hline Pernyataan & V1 & V/2 & V3 & V4 & V5 & Pernyataan & V1 & V2 & V3 & V4 & V5 \\
\hline 1 & 1 & 1 & 1 & 1 & 1 & 1 & 1 & 1 & 1 & 1 & 1 \\
\hline 2 & 1 & 1 & 1 & 1 & 0 & 2 & 1 & 1 & 1 & 1 & 1 \\
\hline 3 & 1 & 1 & 1 & 0 & 1 & 3 & 1 & 1 & 1 & 1 & 1 \\
\hline 4 & 1 & 1 & 1 & 1 & 1 & 4 & 1 & 1 & 1 & 1 & 1 \\
\hline 5 & 1 & 1 & 1 & 1 & 0 & 5 & 1 & 1 & 1 & 1 & 1 \\
\hline 6 & 1 & 1 & 1 & 1 & 1 & 6 & 1 & 1 & 1 & 0 & 0 \\
\hline 7 & 1 & 1 & 1 & 1 & 1 & 7 & 1 & 1 & 1 & 1 & 1 \\
\hline
\end{tabular}




\begin{tabular}{|c|c|c|c|c|c|c|c|c|c|c|c|}
\hline \multicolumn{6}{|c|}{$\begin{array}{l}\text { Validitas Isi } \\
\text { Soal No. } 3\end{array}$} & \multicolumn{6}{|c|}{$\begin{array}{l}\text { Validitas Isi } \\
\text { Soal No. } 4\end{array}$} \\
\hline Pernyataan & V1 & V2 & V3 & V4 & V5 & Pernyataan & V1 & V2 & V3 & V4 & V5 \\
\hline 1 & 1 & 1 & 1 & 1 & 1 & 1 & 1 & 1 & 1 & 1 & 1 \\
\hline 2 & 1 & 1 & 1 & 0 & 1 & 2 & 1 & 1 & 1 & 1 & 1 \\
\hline 3 & 1 & 1 & 1 & 1 & 1 & 3 & 1 & 1 & 1 & 1 & 1 \\
\hline 4 & 1 & 1 & 1 & 1 & 1 & 4 & 1 & 1 & 1 & 1 & 0 \\
\hline 5 & 1 & 0 & 1 & 1 & 1 & 5 & 1 & 1 & 1 & 1 & 1 \\
\hline 6 & 1 & 1 & 1 & 1 & 1 & 6 & 1 & 1 & 1 & 1 & 1 \\
\hline 7 & 1 & 1 & 1 & 1 & 1 & 7 & 0 & 1 & 1 & 1 & 1 \\
\hline
\end{tabular}

Hasil pertimbangan para ahli seperti yang disajikan pada Tabel 3 di atas, selanjutnya dianalisis dengan statistik $Q$ Cochran. Hasil uji statistik tersebut digunakan untuk mengetahui apakah para penimbang instrumen secara sama atau tidak. Hasil uji statistik tersebut dapat disajikan pada Tabel 4 berikut.

Tabel 4. Uji Q-Cochran Validitas Isi TKBKM

\begin{tabular}{|c|c|c|c|c|c|c|c|}
\hline \multicolumn{2}{|l|}{ Soal No 1} & \multicolumn{2}{|l|}{ Soal No 2} & \multicolumn{2}{|l|}{ Soal No 3} & \multicolumn{2}{|l|}{ Soal No 4} \\
\hline \multicolumn{2}{|c|}{ Test Statistics } & \multicolumn{2}{|c|}{ Test Statistics } & \multicolumn{2}{|c|}{ Test Statistics } & \multicolumn{2}{|c|}{ Test Statistics } \\
\hline $\begin{array}{l}\text { N } \\
\text { Cochran's Q } \\
\text { df } \\
\text { Asymp. Sig. }\end{array}$ & $\begin{array}{r}7 \\
5.333^{a} \\
4 \\
.255\end{array}$ & $\begin{array}{l}\text { N } \\
\text { Cochran's Q } \\
\text { df } \\
\text { Asymp. Sig. }\end{array}$ & $\begin{array}{r}7 \\
4.000^{a} \\
4 \\
.406\end{array}$ & $\begin{array}{l}\text { N } \\
\text { Cochran's Q } \\
\text { df } \\
\text { Asymp. Sig. }\end{array}$ & $\begin{array}{r}7 \\
3.000^{\mathrm{a}} \\
4 \\
4 \\
.558 \\
\end{array}$ & $\begin{array}{l}\text { N } \\
\text { Cochran's Q } \\
\text { df } \\
\text { Asymp. Sig. }\end{array}$ & $\begin{array}{r}7 \\
3.000^{a} \\
4 \\
458 \\
\end{array}$ \\
\hline \multicolumn{2}{|c|}{$\begin{array}{l}\text { a. } 1 \text { is treated as a } \\
\text { success. }\end{array}$} & \multicolumn{2}{|c|}{$\begin{array}{l}\text { a. } 1 \text { is treated as a } \\
\text { success. }\end{array}$} & \multicolumn{2}{|c|}{$\begin{array}{l}\text { a. } 1 \text { is treated as a } \\
\text { success. }\end{array}$} & \multicolumn{2}{|c|}{$\begin{array}{l}\text { a. } 1 \text { is treated as a } \\
\text { success. }\end{array}$} \\
\hline
\end{tabular}

Dari Tabel 4 di atas terlihat bahwa taraf signifikansi untuk butir soal nomor 1 adalah 0,255, butir soal nomor 2 sebesar 0,406, nomor 3 sebesar 0,558 dan nomor 4 sebesar 0,558. Taraf signifikansi keempat butir soal tersebut lebih besar dari taraf signifikansi $\alpha=0,05$. Maka dapat disimpulkan bahwa para penimbang telah melakukan validasi isi setiap butir soal tes kemampuan berpikir kreatif matematis secara sama atau seragam.
Setelah instrumen dinyatakan memenuhi validitas isi dan validitas muka, selanjutnya soal test kemampuan berpikir kreatif matematis (TKBKM) diujicobakan kepada 30 siswa kelas XII SMK Teknologi Manufaktur Indonesia Kuningan. Dari data ujicoba soal tes serta perhitungan validitas dan reliabilitas tes dengan menggunakan bantuan Program Microsoft Excel dan SPSS for Windows. Validitas butir soal digunakan dengan korelasi product moment dari Carl Person antara skor 
TKBKM dengan skor totalnya, sedangkan untuk reliabilitas tes digunakan analisa Alpha Cronbach. Hasil perhitungan diperoleh validitas tes disajikan pada Tabel berikut.

Tabel 5. Hasil perhitungan uji validitas Product Moment Pearson

\begin{tabular}{|l|l|l|l|}
\hline $\begin{array}{l}\text { Nomor } \\
\text { Soal }\end{array}$ & $\begin{array}{l}\text { Koefisien } \\
\text { Validitas }\end{array}$ & $\begin{array}{l}\text { Kriteria } \\
\text { Validitas }\end{array}$ & Ket \\
\hline 1 & 0,748 & Tinggi & Dipakai \\
\hline 2 & 0,693 & Tinggi & Dipakai \\
\hline 3 & 0,78 & Tinggi & Dipakai \\
\hline 4 & 0,737 & Tinggi & Dipakai \\
\hline
\end{tabular}

Dari tabel di atas dapat kita lihat nilai koefisien pearson untuk masingmasing butir soal. Untuk soal no 1 didapat $r_{x y}=0,748$ termasuk kategori tinggi, untuk soal no 2, didapat $r_{x y}=0,693$ termasuk kategori tinggi, untuk soal no 3 didapat $r_{x y}=$ 0,780 termasuk kategori tinggi serta soal no 4 didapat $r_{x y}=0,748$ dan termasuk kategori tinggi.

Dari hasil analisis data uji coba seperti terlihat pada Tabel di atas, bahwa nilai signifikansi untuk setiap butir lebih besar dari $\alpha=0,05$, dengan demikian bahwa setiap butir soal tes kemampuan berpikir kreatif matematis dinyatakan valid dengan kategori tingi.

Perhitungan koefisien reliabilitas TKBKM dilakukan dengan menggunakan rumus Alpha Cronbach. Dengan menggunakan bantuan SPSS, diperoleh data reliabilitas soal TKBKM sebagai berikut :
Tabel 6. Hasil perhitungan uji reliabilitas Alpha Cronbach

Reliability Statistics

\begin{tabular}{|c|r|}
\hline $\begin{array}{c}\text { Cronbach's } \\
\text { Alpha }\end{array}$ & N of Items \\
\hline .713 & 4 \\
\hline
\end{tabular}

Dari tabel 6 di atas, diperoleh nilai koefisien reliabilitas sebesar $r=0,713$ dan termasuk kategori tinggi. Hasil analisis uji validitas dan reliabilitas menunjukkan bahwa soal tes kemampuan berpikir kreatif matematis telah memenuhi karakteristik yang memadai untuk digunakan pada penelitian.

Setelah dilakukan uji validitas dan reliabilitas, analisis instrumen TKBKM dilanjutkan dengan menentukan daya pembeda dan tingkat kesukaran soal tes. Untuk menentukan indeks daya pembeda dan tingkat kesukaran, peneliti mengujicobakan soal TKBKM kepada 30 responden.

Indeks daya pembeda (DP) dan tingkat kesukaran dari masing-masing butir soal dapat dilihat pada Tabel 7 berikut.

Tabel 7. Indeks Daya Pembeda dan Tingkat Kesukaran Soal TKBKM

\begin{tabular}{|l|l|l|l|l|}
\hline $\begin{array}{c}\text { No } \\
\text { Soal }\end{array}$ & $\begin{array}{c}\text { Daya } \\
\text { Pembeda }\end{array}$ & $\begin{array}{c}\text { Krite } \\
\text { ria }\end{array}$ & $\begin{array}{c}\text { Tingkat } \\
\text { Kesukaran }\end{array}$ & Kriteria \\
\hline 1 & 0,52 & Baik & 0,53 & Sedang \\
\hline 2 & 0,45 & Baik & 0,51 & Sedang \\
\hline 3 & 0,43 & Baik & 0,42 & Sedang \\
\hline 4 & 0,42 & Baik & 0,34 & Sedang \\
\hline
\end{tabular}


Dari data di atas, keempat butir soal memiliki indeks daya pembeda yang baik serta tingkat kesukaran yang sedang. Oleh karena itu, soal TKBKM yang telah dibuat telah memenuhi dilihat dari aspek indeks daya pembeda dan kesukaran soal.

\section{KESIMPULAN}

Dari hasil analisis dan pembahasan dapat disimpulkan bahwa tes kemampuan berpikir kreatif matematis (TKBKM) telah disusun dan divalidasi oleh para ahli di bidang pendidikan matematika dari segi muka dan isi, hasilnya pendapat para ahli seragam mengenai instrumen TKBKM. Instrumen ini juga memiliki kriteria validitas yang tinggi, serta memiliki kriteria reliabilitas tinggi. Tes tesebut juga memiliki daya pembeda yang baik dantingkat kesukaran yang sedang. Dengan demikian butir soal Instrumen Tes Kemampuan Berpikir Kreatif Matematis (TKBKM) ini dapat digunakan sebagai instrumen pengumpulan data penelitian.

\section{SARAN}

Pada proses penelitian ini, peneliti menemukan beberapa hal yang bisa menjadi bahan untuk penelitian berikutnya. Diantaranya adalah tipe instrumen tes kemampuan berpikir kreatif matematis ada baiknya tidak selalu berbentuk uraian. Bentuk pilihan ganda bisa menjadi alternatif instrumen penelitian karena pada kenyataanya, siswa sering sekali dihadapkan dalam tes yang berbentuk pilihan ganda.

\section{DAFTAR PUSTAKA}

Arikunto. 2003. Dasar-Dasar Evaluasi

Pendidikan. Jakarta: Bumi Aksara

Arsyad, Nurdin. 2016. Model

Pembelajaran Menumbuhkembangkan

Kemampuan Metakognitif. Makassar :

Pustaka Refleksi

Ismaimuza, D. (2010). Kemampuan

Berpikir kritis dan Kreatif Matematis

Siswa SMP melalui Pembelajaran

Berbasis Masalah dengan Strategi

Konflik Kognitif. Disertasi Doktor pada

SPS UPI: Tidak diterbitkan.

Kemendikbud. 2013. Handout Pelatihan

Kurikulum 2013. Jakarta:

Kemendikbud

Nunuk, B.K. (2019). Kreativitas Peserta

Didik di Era Abad 21 Itu Dibutuhkan.

[Online] diakses dari

https://radarkudus.jawapos.com/read/

2019/03/19/126002. (20 Oktober

2020)

Permendikbud. (2006). Standar

Kompetensi Lulusan. Tidak Diterbitkan (2018). Standar

Kompetensi Lulusan. Tidak Diterbitkan

Siegel, S. 1986. Statistik Non-Parametrik

Untuk Ilmu-ilmu Sosial. Jakarta :

Gramedia 
Sugiyono. 2011. Metode Penelitian

Pendidikan Pendekatan Kuantitatif, Kualitatif, dan R \& D. Bandung :

Alfabeta.

Suherman, E. 2003. Evaluasi

Pembelajaran Matematika. Bandung: JICA UPI 